\title{
Geographic variation in halogenated furanones from the red alga Delisea pulchra and associated herbivores and epiphytes
}

\author{
J. T. Wright ${ }^{1, *}$, R. de Nys ${ }^{1,2}$, P. D. Steinberg ${ }^{1,2}$ \\ ${ }^{1}$ School of Biological Science, The University of New South Wales, New South Wales 2052, Australia \\ ${ }^{2}$ Centre for Marine Biofouling and Bio-Innovation, The University of New South Wales, New South Wales 2052, Australia
}

\begin{abstract}
We examine patterns of quantitative variation in halogenated furanones, secondary metabolites of Delisea pulchra (Rhodophyta; Bonnemaisoniales), and how this relates to variation in local abundance of herbivores and epiphytes. Fifteen populations of $D$. pulchra covering a distance of $650 \mathrm{~km}$ of temperate southeastern Australia were sampled. Concentrations of the 4 main furanones in D. pulchra (Compounds 1 to 4 ) showed large variability but there was no latitudinal trend to this variation. We found significant variation in the concentrations of both total and individual furanones among locations, between summer and winter, and between different life-history stages. Importantly, the range of total furanone concentration among plants within locations was large, often varying by an order of magnitude or more. A total of 5 species of herbivorous fish, 7 species of macroinvertebrate grazer and 6 groups of mesograzer (of varying taxonomic level) were found at the 15 locations. The abundance of both total macroinvertebrate grazers and total mesograzers known to consume D. pulchra varied significantly among locations. However, correlations between furanones and the abundance of macroinvertebrate grazers and mesograzers at the scale of location were all weak and nonsignificant, as was the correlation between furanones and the abundance of epiphytes on $D$. pulchra. The large variability in concentrations of furanones, and the absence of any positive relationships between furanones, herbivores and epiphytes, suggest that quantitative variation in furanones in $D$. pulchra is not driven by population-level selection or induction, but is more likely to be a result of small-scale variation in environmental factors such as nutrients and light, and genetic differences among individual plants.
\end{abstract}

KEY WORDS: Australia $\cdot$ Chemical ecology $\cdot$ Delisea pulchra $\cdot$ Epiphytes $\cdot$ Furanones $\cdot$ Herbivory Macroinvertebrate grazers $\cdot$ Mesograzers $\cdot$ Red algae $\cdot$ Secondary metabolites

\section{INTRODUCTION}

A large number of terrestrial and marine plants produce secondary metabolites that provide a defence against natural enemies (e.g. Rosenthal \& Berenbaum 1992). For terrestrial plants, patterns of quantitative variation in secondary metabolites within species are

*Present address: Bodego Marine Laboratory, PO Box 247, Bodega Bay, California 94923, USA.

E-mail: jtwright@ucdavis.edu well documented and have provided a basis for understanding the ecology and evolution of host-plant resistance (Fritz \& Simms 1992 and references therein). For marine algae, patterns of quantitative variation in secondary metabolites within species are, in general, poorly described. Much of the work examining variation in algal secondary metabolites has focussed on differences in the concentration of brown algal phlorotannins, which are structurally uncharacterised compounds, and therefore measured as total phlorotannins (reviews by Steinberg 1992, Targett \& Arnold 1998). Furthermore, 
differences in total phlorotannins are often examined among species at large geographic scales (Steinberg 1989, Van Alstyne \& Paul 1990, Steinberg \& Van Altena 1992, Targett et al. 1992, Van Alstyne et al. 1999). For example, total phlorotannins in temperate Australasian brown algae occur generally at higher concentrations than total phlorotannins in temperate North American brown algae. Herbivory may also be more intense in temperate Australasia, leading to models proposing herbivores as an important evolutionary force driving high phlorotannin concentrations in brown algae from that region (Steinberg 1989, Steinberg \& Van Altena 1992, Steinberg et al. 1995). Studies of brown algae where variation within species has been examined show that total phlorotannins can differ among populations separated by as little as $5 \mathrm{~km}$ and between the same populations sampled at different times (Steinberg 1989, Steinberg \& Van Altena 1992, Pavia \& Aberg 1996, Van Alstyne et al. 1999). The limited data available for individual non-polar secondary metabolites from marine algae reveal that similar levels of variation can occur over the same spatial and temporal scales (Cronin \& Hay 1996c, Puglisi \& Paul 1997).

Descriptions of quantitative variation in algal secondary metabolites within species are important; this is the variation on which evolution acts (Hay \& Steinberg 1992, Hay 1996). Concentrations of algal secondary metabolites can vary as a function of environmental factors such as nutrients, light and desiccation (Yates \& Peckol 1993, Arnold et al. 1995, Cronin \& Hay 1996a,b, Pavia et al. 1997) and induction by herbivores (Van Alstyne 1988, Cronin \& Hay 1996c) but it is not known whether such variation could also be due to genetic factors. Quantitative variation has important consequences because chemical deterrence of marine herbivores and epiphytes is usually concentration dependent (e.g. Hay et al. 1987, Steinberg 1988, de Nys et al. 1995, Schmitt et al. 1995). Thus, studies describing patterns of variation in algal secondary metabolites, herbivores and epiphytes will provide important background information that will contribute to the current understanding of chemical resistance in marine algae.

In this paper we examine, at the population level, the relationship between quantitative variation in the secondary metabolites of the red alga Delisea pulchra and variation in the abundance of co-occurring herbivores and epiphytes. D. pulchra produces non-polar secondary metabolites (furanones; de Nys et al. 1992, 1993) that deter herbivores (Wright et al. unpubl.), deter settlement of epiphytes (de Nys et al. 1995) and reduce attachment of bacteria (Maximilien et al. 1998). Importantly, the activity of the furanones against epiphytes and bacteria varies both with compound and concentration (de Nys et al. 1995, Maximilien et al. 1998). In this study, we (1) document the extent of spatial and

temporal variation in concentrations of furanones in $D$. pulchra among 15 populations covering a distance of $650 \mathrm{~km}$ of temperate southeastern Australia, (2) document variation in the abundance of herbivores (macroand mesograzers) and epiphytes in shallow $(<4 \mathrm{~m})$ subtidal reefs where $D$. pulchra occurred at each of the 15 locations, (3) examine correlations between furanones and the abundance of herbivores and epiphytes, and (4) examine variation in the abundance of the different life-history stages of $D$. pulchra at each of the locations and determine whether concentrations of furanones differed between life-history stages.

\section{MATERIALS AND METHODS}

Natural history and secondary metabolites of Delisea pulchra. Delisea pulchra (Greville) Montagne (Bonnemaisoniales, Rhodophyta) is a medium-sized (typically $150 \mathrm{~mm}$ in height) shallow subtidal alga, occurring in waters throughout southern Australia, the Antarctic Peninsula and various Subantarctic Islands (Ricker 1987, Bonin \& Hawkes 1988, Millar 1990). In southeastern Australia it is one of the more common foliose algae in the sublittoral zone (Millar 1990). It has been described as having a triphasic life history typical of algae in the Bonnemaisoniales, with free-living haploid (gametophytes) and diploid (tetrasporophyte) stages and a further diploid stage (carposporophyte) that remains attached to the female gametophyte (Bonin \& Hawkes 1988, Womersley 1996). Gametophytes can be either monoecious or dioecious and are isomorphic with tetrasporophytes (Bonin \& Hawkes 1988, Womersley 1996). D. pulchra contains a range of halogenated furanones, of which 4 make up approximately $95 \%$ of the total amount of furanones in the alga (Fig. 1; de Nys et al. 1992, 1993).

Study locations. Delisea pulchra on the southeastern Australian coast was sampled in August 1994 (hereafter winter 1994) and January/February 1995 (hereafter summer 1995). In winter 1994, we sampled $D$. pulchra at 9 locations from Nobby's Beach in the north $\left(32^{\circ} 55^{\prime} \mathrm{S}, 151^{\circ} 47^{\prime} \mathrm{E}\right)$ to Kiama in the south $\left(34^{\circ} 40^{\prime} \mathrm{S}\right.$, $150^{\circ} 51^{\prime} \mathrm{E}_{\text {; Fig. }}$ ). These initial surveys examined vari-

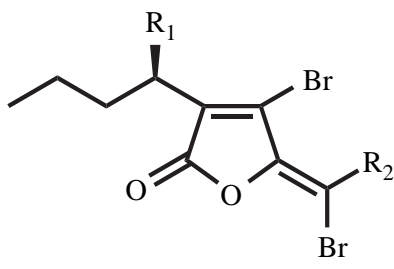

Furanone

\section{$\underline{\mathrm{R} 1} \mathrm{R} 2$}

(1) $\mathrm{H} \quad \mathrm{Br}$

(2) $\mathrm{H} \quad \mathrm{H}$

(3) OAc H

(4) $\mathrm{OH} \mathrm{H}$

Fig. 1. Structure of the major secondary metabolites of Delisea pulchra (Compounds 1 to 4 ) 

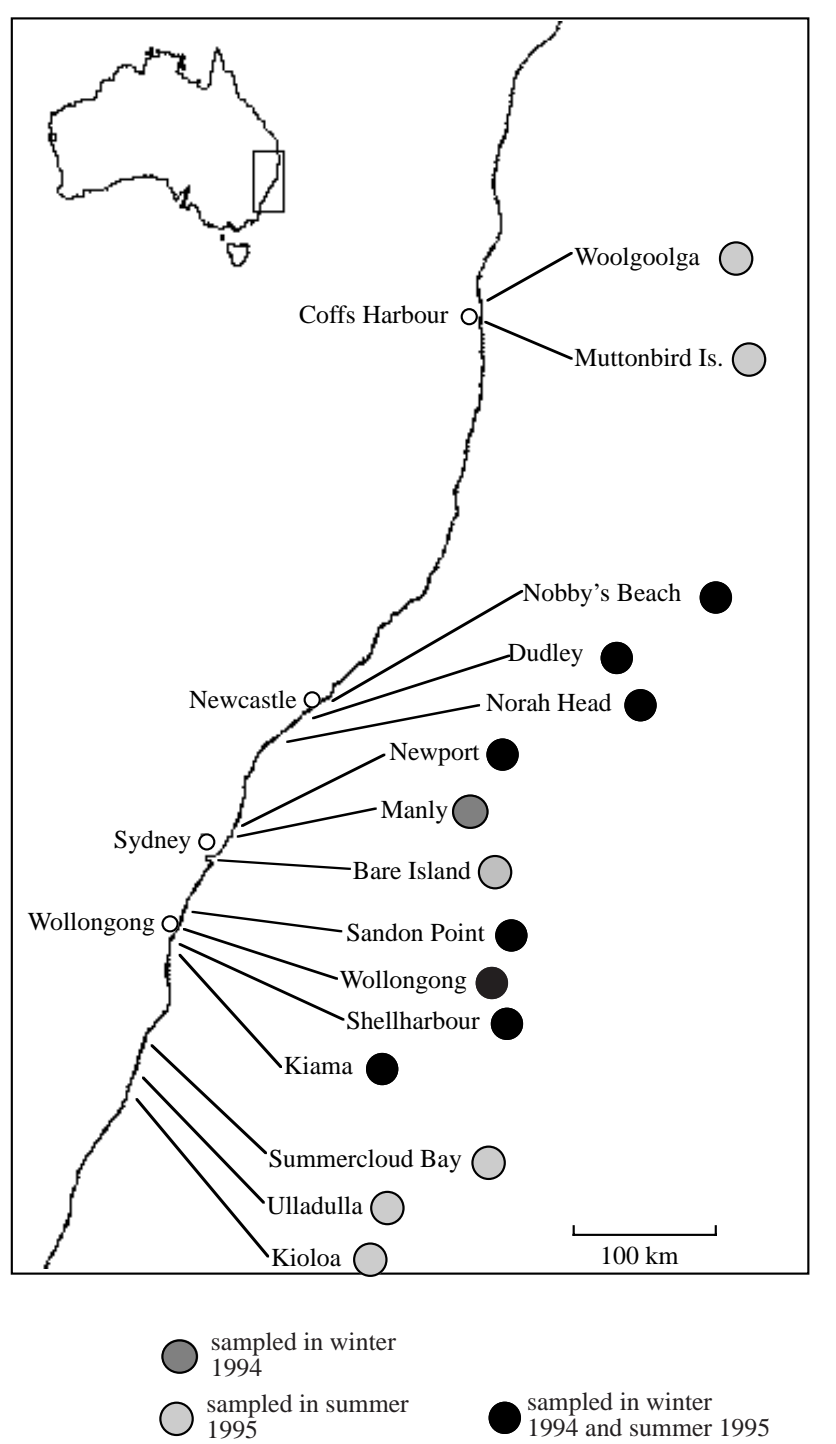

Fig. 2. Locations sampled for variation in life history, secondary metabolites, herbivores and epiphytes

ation among locations in (1) concentrations of the 4 main furanones and (2) the proportion of different lifehistory stages in each population. In summer 1995, we sampled those 9 locations again (except Manly, where no plants could be found) and also a further 6 locations, extending the distance covered in the survey to $650 \mathrm{~km}$ from Woolgoolga in the north $\left(30^{\circ} 07^{\prime} \mathrm{S}, 153^{\circ} 12^{\prime} \mathrm{E}\right)$ to Kioloa in the south $\left(35^{\circ} 33^{\prime} \mathrm{S}, 150^{\circ} 22^{\prime} \mathrm{E}\right)$. Although all the locations sampled occur within a single biogeographical region (Womersley 1990), sea temperature over that distance decreases from north to south, ranging from a mean summer temperature of $25^{\circ} \mathrm{C}$ in the most northerly locations (Woolgoolga and Coffs Harbour) to $21^{\circ} \mathrm{C}$ in the most southerly locations (Jeffrey et al. 1990). The relative temperature differences are sim- ilar in winter and relate to the movement of the East Australian Current, which flows south down the east Australian coast until $33^{\circ} \mathrm{S}$ (near Sydney) where it moves away from the continent in a southeast direction (Jeffrey et al. 1990). The summer 1995 surveys assessed variation among locations in (1) concentrations of the 4 main furanones, (2) density of herbivores (fish, macroinvertebrates and mesograzers), (3) epiphyte loads on D. pulchra, and (4) the proportion of different lifehistory stages. There were differences among the locations in terms of their orientation, exposure to waves etc. and also in the densities of $D$. pulchra, which ranged from 0.2 to 43.2 plants $\mathrm{m}^{-2}$. However, there were no obvious morphological differences in D. pulchra at the different locations and sampling at all locations was done at approximately the same depth, 2 to $4 \mathrm{~m}$.

Furanone extraction and gas chromatography-mass spectrometry. The concentrations of the 4 main furanones in Delisea pulchra was determined using gas chromatography-mass spectrometry (GC-MS) following the methods of de Nys et al. (1996). Eight plants in winter 1994 and 10 plants in summer 1995 were haphazardly collected from each location, placed into individual plastic bags and frozen at $-20^{\circ} \mathrm{C}$. These plants were then freeze dried, ground to a powder, and $100 \mathrm{mg}$ (dry weight) of tissue from each plant extracted 5 times with $2 \mathrm{ml}$ of dichloromethane. The 5 combined extracts were filtered $(0.2 \mu \mathrm{m}$ pore size), dried and redissolved in $1 \mathrm{ml}$ ethyl acetate containing naphthalene $(10 \mu \mathrm{g}$ $\mathrm{ml}^{-1}$ ) as an internal standard prior to analysis with GCMS. Furanones are stable at room temperature under normal light conditions and thus our collection and handling was unlikely to have had any effect on their calculated concentrations.

Gas chromatography was performed with a Hewlett Packard (HP) 5890 Series II gas chromatograph (GC) and a polyamide-coated fused-silica capillary column (BP5, $12 \mathrm{~m}$ long, $0.22 \mathrm{~mm}$ i.d., $0.25 \mu \mathrm{m} 5 \%$ phenyl [equiv.] polysilphenylene-siloxane stationary phase, SGE Pty Ltd). All injections were performed in the splitless mode with an inlet pressure of 3 psi. Glass wool $\left(5 \mathrm{~mm}^{-2}\right)$ was inserted into the injection port liner. The injection port was held at $280^{\circ} \mathrm{C}$ and the interface at $300^{\circ} \mathrm{C}$. The GC was held at $50^{\circ} \mathrm{C}$ for $1.5 \mathrm{~min}$, ramped at $20^{\circ} \mathrm{C} \mathrm{min}{ }^{-1}$ to $250^{\circ} \mathrm{C}$, then ramped at $50^{\circ} \mathrm{C} \mathrm{min}^{-1}$ to $320^{\circ} \mathrm{C}$, where it was held for $4 \mathrm{~min}$. Helium was used as the carrier gas. Mass spectrometry was performed with a HP 5971 massselective detector (MSD). Ions characteristic of the internal standard and Compounds 1 to 4 were monitored in the selective-ion monitoring mode. Standards used in the GC-MS analysis were isolated from dichloromethane extract of freeze-dried Delisea pulchra. Metabolites were identified by comparison of ${ }^{1} \mathrm{H}$ and ${ }^{13} \mathrm{C}$ nuclear magnetic resonance (NMR) data (de Nys et al. 1993). Compounds 1 to 4 were quantified by measuring the 
peak areas for each compound and the internal standard. The ratio of peak areas (compound:internal standard) was calculated for each metabolite and converted to concentration by reference to standard curves.

Abundance of herbivores and epiphytes. The density of all herbivores (fishes, macroinvertebrates, mesograzers known to consume Delisea pulchra, and all other mesograzers) was determined at each of the 14 locations (except for Woolgoolga) in summer 1995 at the same time and place as $D$. pulchra was collected. Herbivorous fish were counted at each location by establishing three $20 \mathrm{~m}$ transects and recording all herbivorous fish seen during a swim along each transect. The accuracy of this method is dependent on water visibility and the chance that mobile species (e.g. Girella tricuspudata) are in the area at the time of the survey. As we cannot be sure that visibility was consistent at all locations, or that fish present at each location were always counted in the surveys, the data for fish are treated qualitatively. In southeastern Australia, the kelp specialist Odax cyanomelas can clear patches of Ecklonia radiata (Andrew \& Jones 1990; see also Choat 1982, Choat \& Clements 1992). To our knowledge, no fish have ever been recorded consuming $D$. pulchra and we too did not observe this. Macroinvertebrate herbivores (sea urchins and large gastropods) were counted at each location by setting up three $10 \times 10 \mathrm{~m}$ sites and randomly sampling ten $0.5 \times 0.5 \mathrm{~m}$ quadrats within each site. Although macrograzers do consume $D$. pulchra, it is a very low preference food for them (Steinberg \& Van Altena 1992). Mesograzers are small invertebrate herbivores less than $2.5 \mathrm{~cm}$ in length, and can include juveniles of some larger species (Brawley 1992). The abundance of mesograzers on $D$. pulchra was examined on 10 haphazardly collected plants at each location. These plants were removed from the substratum and placed into individual plastic bags, which were immediately sealed. On shore, the entire contents of each bag were poured into a plastic jar containing $5 \%$ formaldehyde in seawater. In the laboratory, the contents of each jar were poured through a $300 \mu \mathrm{m}$ sieve and the plants washed several times with fresh water to remove all animals. This technique removes 94 to $98 \%$ of all mesograzers (Poore \& Steinberg 1999). Individual mesograzer species (echinoids, gastropods, isopods; see Table 5) or herbivorous taxa (polychaetes, amphipods, insects; Brawley 1992) were identified, counted, oven dried at $100^{\circ} \mathrm{C}$ for $24 \mathrm{~h}$ and weighed. Mesograzers known to consume D. pulchra had been previously determined by either feeding experiments (Rogers et al. 1995) or gut content analysis of field-collected animals (Wright unpubl.). We expressed the abundance of mesograzers on plants at each location in 2 ways: number of animals $\mathrm{g}^{-1}$ plant, and dry mass (mg) of animals $\mathrm{g}^{-1}$ plant.
Epiphyte load on Delisea pulchra was considered to be the total biomass of epiphytes per plant ( $\mathrm{mg} \mathrm{g}^{-1}$ dry weight) and was measured by removing epiphytes from plants with forceps, drying them at $100^{\circ} \mathrm{C}$ for $24 \mathrm{~h}$, and weighing them. Ten plants were sampled at each location.

Proportion of life-history stages. The life-history stages of Delisea pulchra were identified visually by the presence of different reproductive structures. At most locations there were some small plants with no reproductive structures and these were designated as non-reproductive. To determine the proportion of the different life-history stages in winter 1994, 50 plants were haphazardly collected from each location (except Norah Head, where only 3 plants were found). In summer 1995, 30 to 50 plants were collected from the 6 locations that had not been sampled in winter 1994 (except Woolgoolga, where only 7 plants were found), and 9 to 10 plants were collected from locations that were sampled in winter 1994 (except Nobby's Beach and Kiama, where 49 and 44 plants were collected, respectively). Plants were removed from the substratum, placed into individual plastic bags and examined for reproductive structures back in the laboratory.

Statistical analyses. Statistical analyses were carried out using SYSTAT (Wilkinson 1997). Analyses of variance (ANOVAs) were checked for normality and heterogeneity of variance using frequency histograms of residuals and plots of residuals versus means, respectively. Logarithmic or arcsine transformations were performed as appropriate and are shown in the relevant table legends. Following ANOVAs, post-hoc tests (Tukey's multiple range) were performed where required.

Spatial patterns of quantitative variation in the 4 main furanones of Delisea pulchra were analysed in 3 ways. First, we compared the total concentration of furanones in plants between locations using ANOVA. Second, we compared the concentrations of the individual compounds using a 3-factor ANOVA with the factors location, compounds and plants (blocked factor). Plant was included as a blocked factor as it is possible that individual secondary metabolites within a plant are not independent of each other (Pennings \& Paul 1993, de Nys et al. 1996). These 2 analyses were done separately for both winter 1994 and summer 1995 samples. Finally, for the 8 locations sampled in both winter 1994 and summer 1995, we performed analyses that included the additional factor of time and determined whether the concentration of total or individual furanones differed in plants from these locations collected at the 2 times.

To determine whether the concentrations of secondary metabolites differed between life-history stages (haploid vs diploid) and reproductive status (reproductive or nonreproductive), we determined the concentration of total 
and individual furanones in reproductive diploid and haploid plants, and non-reproductive plants, from the one site where gametophytes occurred (Nobby's Beach). In winter 1994, we compared furanones in 8 tetrasporophytes and 5 female gametophytes. In summer 1995, we compared furanones in 5 tetrasporophytes, 5 female gametophytes and 5 non-reproductive plants. No male gametophytes were found at any locations in either season. The total concentration of furanones in the different life-history stages was analysed with an unpaired $t$-test in winter 1994 and a 1-factor ANOVA in summer 1995. Concentrations of the individual furanones in the different life-history stages were analysed at both times using a 3-factor ANOVA with the factors life-history stage, compounds and plants (blocked factor).

For herbivores, the main aim was to compare the relative abundance of macrograzers and mesograzers known to consume Delisea pulchra among locations, and use this as an estimate of grazing pressure. To examine variation in the abundance of macrograzers, we pooled all sea urchins and large herbivorous gastropods and determined whether there was variation in the total density of these species among locations using a nested ANOVA with the factors location and sites nested within location. Two estimates of mesograzer abundance were examined: the total number of mesograzers which consume D. pulchra per plant (standardised for plant dry weight) and the total biomass of these species per plant (mg mesograzers $\mathrm{g}^{-1}$ dry weight). For both of these measures, 1-factor ANOVAs were performed to test for differences among locations.

The total mass of epiphytes per plant (mg epiphytes $\mathrm{g}^{-1}$ dry weight) was analysed with a 1-factor ANOVA following an arcsine transformation of the data.

To examine relationships between furanones and the abundance of herbivores and epiphytes, correlations were performed between total furanones and the abundance of macroinvertebrates, the abundance and biomass of mesograzers, and the biomass of epiphytes.

\section{RESULTS}

\section{Spatial patterns of variation in secondary metabolites}

The total concentration of furanones differed significantly in plants from different locations in both winter 1994 (1-factor ANOVA; $F_{8,58}=4.945, \mathrm{p}<0.001$ ) and summer 1995 (1-factor ANOVA; $F_{13,122}=8.249, \mathrm{p}<0.001$; Fig. 3). In winter 1994, mean total concentrations ranged from $3.7 \mathrm{mg} \mathrm{g}^{-1}$ at Wollongong to $26.1 \mathrm{mg} \mathrm{g}^{-1}$ at Norah Head. In summer 1995, mean concentrations were generally much lower and ranged from $1.53 \mathrm{mg} \mathrm{g}^{-1}$ at Ulladulla to $8.19 \mathrm{mg} \mathrm{g}^{-1}$ at Dudley. For the 8 locations sam- (a)

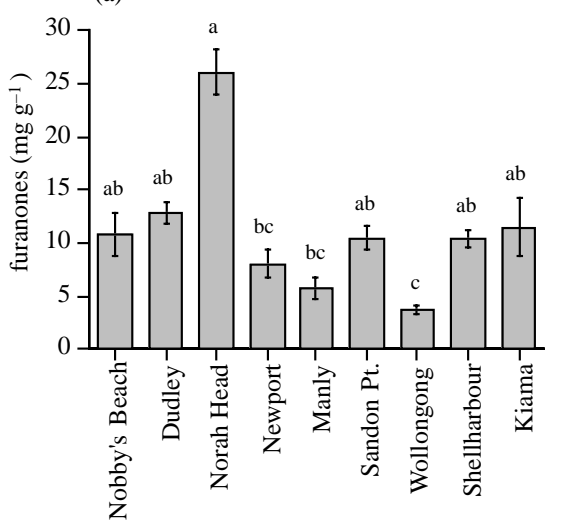

(b)

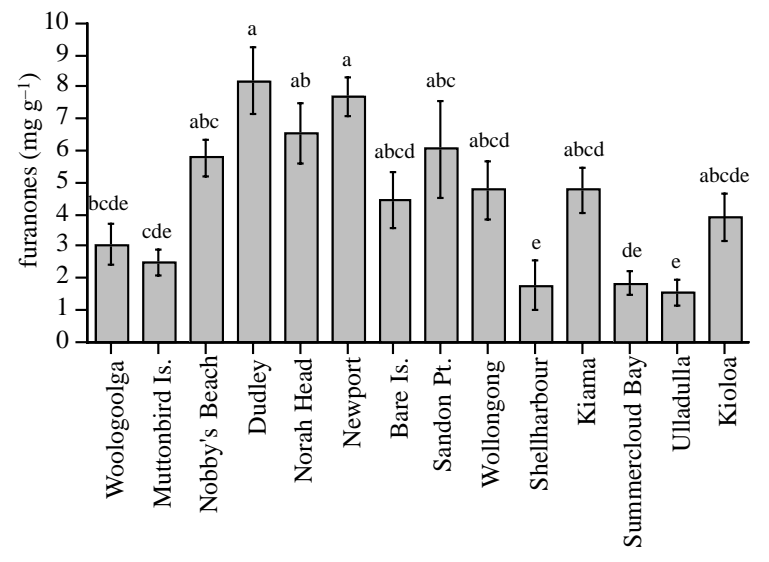

Fig. 3. Total concentration (mean $\pm 1 \mathrm{SE}$ ) of furanones in plants collected from each location in (a) winter $1994(\mathrm{n}=8)$ and (b) summer $1995(\mathrm{n}=10)$. Locations sharing the same letter do not differ at $p=0.05$ (Tukey's analysis). In this and subsequent figures, sites are arranged from north (left) to south (right)

pled in both times, plants collected in winter 1994 had a significantly higher concentration of total furanones compared to summer 1995 (Table 1). However, there was a significant time $\times$ location interaction (Table 1 ), indicating that this result was not consistent across all locations. Plants at Wollongong had higher total concentrations in summer 1995 than in winter 1994. There was no correlation between winter 1994 and summer 1995 in the mean total concentration of furanones for the 8 locations sampled at both times $(\mathrm{r}=0.221, \mathrm{p}=0.599)$.

Table 1. ANOVAs examining the effect of time on total furanones for the 8 locations sampled in both summer 1994 and winter 1995. Data $\log (x+1)$ transformed

\begin{tabular}{|lrrrr|}
\hline Source & df & MS & $F$ & \multicolumn{1}{c|}{ p } \\
\hline Location & 7 & 1.900 & 1.044 & 0.478 \\
Time & 1 & 10.946 & 6.016 & 0.044 \\
Location $\times$ Time & 7 & 1.819 & 6.313 & $<0.001$ \\
Error & 122 & 0.288 & & \\
\hline
\end{tabular}



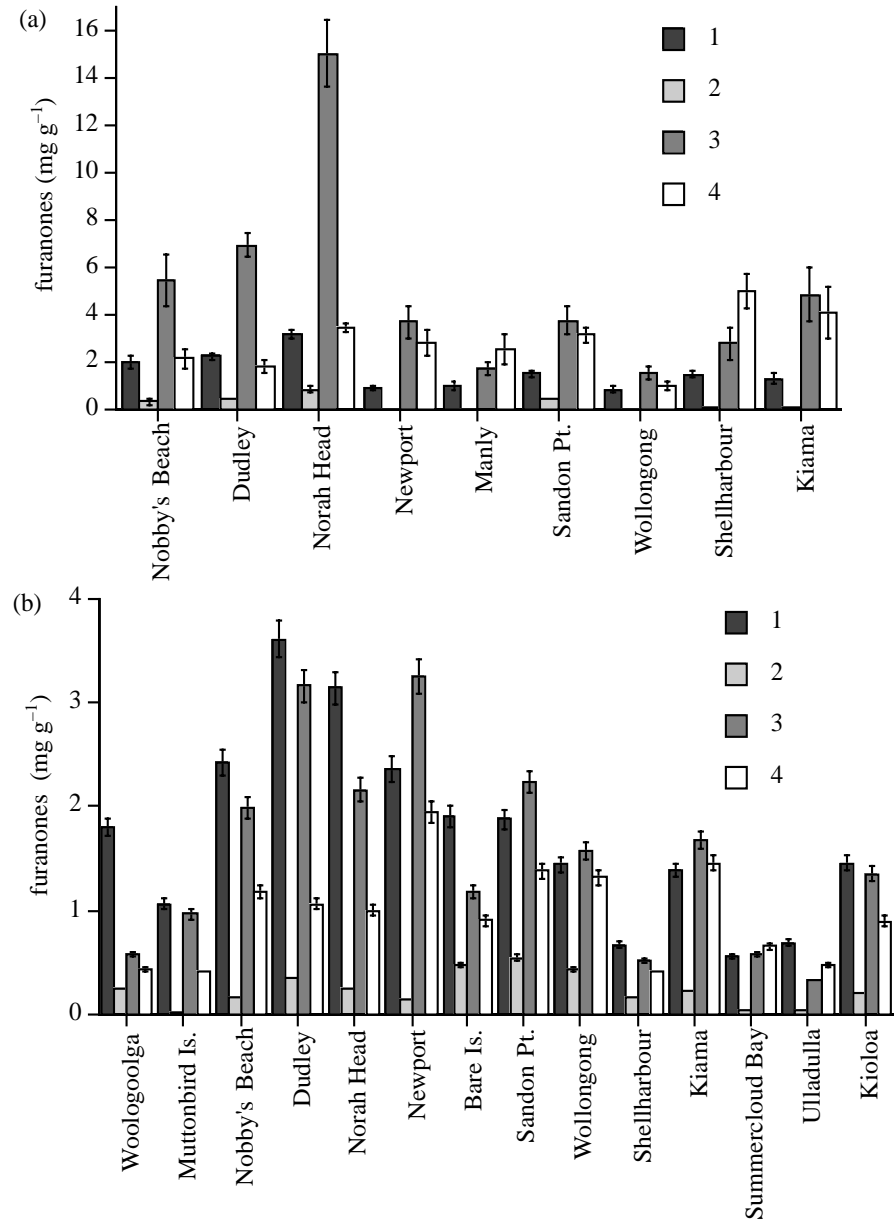

Fig. 4. Concentrations of furanones 1 to 4 (mean $\pm 1 \mathrm{SE}$ ) in plants collected from each location in (a) winter $1994(\mathrm{n}=8)$ and (b) summer $1995(\mathrm{n}=10)$

The range of concentrations of total furanones among plants within locations was large (Table 2). Often there was an order of magnitude difference between the plants having the lowest and highest concentrations. This was consistent across seasons, although it was more marked in summer 1995 than winter 1994.

Concentrations of the individual furanones also varied significantly among locations in both winter 1994 and summer 1995 (Fig. 4, Table 3). However, in both times, these differences among locations varied with compound (significant location $\times$ compound interactions for both seasons; Table 3). A posteriori tests conducted separately for each compound within each season revealed that there were significant differences in the concentrations of all 4 compounds among locations (Tukey's $\alpha<0.05$ ). In general, the patterns of variation for individual furanones tracked the variation among locations for total furanones (Figs. $3 \& 4$ ). In winter 1994, Compound 3 had the highest concentration in plants at 7 out of 9 locations (Fig. $4 \mathrm{a}$ ). At the other 2 locations (Manly and Shellharbour), Compound 4 had the highest concentration. In summer 1995, Compound 1 had the highest concentration in plants from 9 out of the 14 locations (Fig. 4b). At 4 other locations, Compound 3 was at the highest concentration while at one location (Summercloud Bay), Compound 4 was most abundant. In both seasons, Compound 2 generally occurred at lower concentrations than the other 3 compounds.

The analysis including the factor time for the 8 locations sampled in both winter 1994 and summer 1995 emphasised the complex patterns of variation in individual compounds (Table 4). The change in individual compounds between seasons was not consistent across compounds (significant compound $\times$ time interaction). Moreover, the response of individual compounds depended not only on season, but also on location (significant compound $\times$ location and time $\times$ location $\times$ compound interactions; Table 4). As with the total concentrations, there was also a significant location $\times$ time interaction.

\section{Abundance of herbivores and epiphytes}

Species of herbivorous fish recorded in beds of Delisea pulchra were Parma microlepis, P. unifasciata, Girella tricuspudata, Crinodus lophodon, Odax cyanomelas and also unidentified monocanthids (which were most likely omnivorous; Table 5).

Four species of sea urchin (Heliocidaris erythrograma, H. tuberculata, Holopneustes purpurascens, Centrostephanus rodgersii) were present in the surveys. All of these species were reasonably widespread, but only $H$. erythrograma (at Bare Island, Summer-

Table 2. Range of concentrations of total furanones ( $\mathrm{mg} \mathrm{g}^{-1}$ dry weight) in plants within each location in winter 1994 and summer 1995. $\mathrm{n}=$ number of plants; $\mathrm{ns}=$ no sample taken

\begin{tabular}{|lcccc|}
\hline Location & $\mathrm{n}$ & Winter 1994 & $\mathrm{n}$ & Summer 1995 \\
\hline Woolgoolga & - & $\mathrm{ns}$ & 8 & $0.52-5.17$ \\
Muttonbird Island & - & $\mathrm{ns}$ & 10 & $0.99-4.20$ \\
Nobby's Beach & 8 & $1.02-18.25$ & 10 & $3.76-8.60$ \\
Dudley & 8 & $8.69-15.86$ & 10 & $1.97-13.41$ \\
Norah Head & 3 & $22.78-30.16$ & 10 & $3.37-13.09$ \\
Newport & 7 & $2.62-11.76$ & 10 & $5.33-10.43$ \\
Manly & 8 & $2.27-10.41$ & - & $\mathrm{ns}$ \\
Bare Island & - & $\mathrm{ns}$ & 9 & $0.80-8.18$ \\
Sandon Point & 8 & $4.13-14.56$ & 9 & $0.99-13.73$ \\
Wollongong & 8 & $0.59-4.74$ & 10 & $0.32-9.4$ \\
Shellharbour & 8 & $6.51-13.23$ & 10 & $0.05-7.13$ \\
Kiama & 8 & $1.14-22.05$ & 10 & $1.14-7.96$ \\
Summercloud Bay & - & $\mathrm{ns}$ & 10 & $0.31-3.48$ \\
Ulladulla & - & $\mathrm{ns}$ & 10 & $0.30-3.19$ \\
Kioloa & - & $\mathrm{ns}$ & 10 & $0.76-8.19$ \\
\hline
\end{tabular}


Table 3. ANOVAs for individual furanones (Compounds 1 to 4 ) in winter 1994 and summer 1995. Data $\log (x+1)$ transformed for both analyses

\begin{tabular}{|lrrrr|}
\hline Source & df & MS & $F$ & $\mathrm{p}$ \\
\hline Winter 1994 & & & & \\
Location & 8 & 1.656 & 15.249 & $<0.001$ \\
Compound & 3 & 19.943 & 46.570 & $<0.001$ \\
Plant (block) & 7 & 0.308 & 2.833 & 0.008 \\
Location $\times$ Compound & 24 & 0.428 & 3.944 & $<0.001$ \\
Error & 221 & 0.109 & & \\
Summer 1995 & & & & \\
Location & 13 & 2.069 & 23.000 & $<0.001$ \\
Compound & 3 & 15.637 & 48.103 & $<0.001$ \\
Plant (block) & 9 & 0.410 & 4.562 & $<0.001$ \\
Location $\times$ Compound & 39 & 0.325 & 3.613 & $<0.001$ \\
Error & 479 & 0.09 & & \\
\hline
\end{tabular}

Table 4. ANOVA examining the effect of time on individual furanones (Compounds 1 to 4 ) for the 8 locations sampled in both summer 1994 and winter 1995. Data $\log (x+1)$ transformed

\begin{tabular}{|lrrrr|}
\hline Source & df & MS & \multicolumn{1}{c|}{$F$} & $\mathrm{p}$ \\
\hline Location & 7 & 2.074 & 1.224 & 0.398 \\
Compound & 3 & 27.703 & 5.928 & 0.073 \\
Time & 1 & 7.163 & 4.228 & 0.079 \\
Plant (block) & 9 & 0.403 & 3.768 & $<0.001$ \\
Location $\times$ Compound & 21 & 0.583 & 2.320 & 0.030 \\
Location $\times$ Time & 7 & 1.694 & 15.820 & $<0.001$ \\
Compound $\times$ Time & 3 & 4.341 & 17.274 & $<0.001$ \\
Location $\times$ Compound $\times$ Time & 21 & 0.251 & 2.347 & 0.001 \\
Error & 475 & 0.107 & & \\
& & & & \\
\hline
\end{tabular}

cloud Bay and Kioloa) and H. purpurascens (at Bare Island) reached densities above 5 ind. $\mathrm{m}^{-2}$ (Fig. 5). Three species of herbivorous gastropods (Turbo torquatus, T. undulatus, Astralium tentoriformis) were recorded in $D$. pulchra beds. Although T. torquata was widespread, occurring at 11 locations, it was generally in low densities ( 1 ind. $\mathrm{m}^{-2}$; Fig. 5$)$. Only 1 T. undulatus was found at Dudley.

The total density of macroinvertebrate herbivores (Astralium tentoriformis was excluded as it is not known to consume macroalgae) differed significantly among locations $\left(F_{12,24}=10.943, \mathrm{p}<0.001\right)$. Some locations, such as Bare Island and Kioloa, had very high densities, while 2 locations, Muttonbird Island and Ulladulla, had no macroinvertebrates (Fig. 5). Bare Island, Kioloa and Summercloud Bay had significantly higher densities of macroinvertebrates than all other locations (Tukey's $\alpha<0.05$ ) and, to a large extent, this was due to high densities of Heliocidaris erythrograma. The nested ANOVA also revealed significant variation among sites within locations $\left(F_{24,332}=4.009\right.$, $\mathrm{p}<0.001)$, indicating small-scale variation in macroinvertebrate densities.
Table 5. Herbivores co-occurring with Delisea pulchra at 13 locations on the southeastern Australian coast

\begin{tabular}{|c|c|}
\hline Taxon/species & No. of locations present \\
\hline \multicolumn{2}{|l|}{ Fishes } \\
\hline \multicolumn{2}{|l|}{ Pomacentridae } \\
\hline Parma spp. (P. microlepis and P. unifasciata) & 8 \\
\hline \multicolumn{2}{|l|}{ Girellidae } \\
\hline Girella tricuspudata & 4 \\
\hline \multicolumn{2}{|l|}{ Aplodactylidae } \\
\hline Crinodus lophodon & 12 \\
\hline \multicolumn{2}{|l|}{ Odacidae } \\
\hline Odax cyanomelas & 8 \\
\hline Monocanthidae & 3 \\
\hline \multicolumn{2}{|l|}{ Macro-invertebrates } \\
\hline \multicolumn{2}{|l|}{ Echinoidea } \\
\hline Heliocidaris erythrograma & 7 \\
\hline Heliocidaris tuberculata & 6 \\
\hline Holopneustes purpurascens & 8 \\
\hline Centrostephanus rodgersii & 9 \\
\hline \multicolumn{2}{|l|}{ Gastropoda } \\
\hline Turbo torquatus & 11 \\
\hline Turbo undulatus & 1 \\
\hline Astralium tentoriformis & 10 \\
\hline \multicolumn{2}{|l|}{ Mesograzers } \\
\hline \multicolumn{2}{|l|}{ D. pulchra feeders } \\
\hline \multicolumn{2}{|l|}{ Echinoidea } \\
\hline Holopneustes purpurascens & 5 \\
\hline \multicolumn{2}{|l|}{ Gastropoda } \\
\hline Phasianotrochus eximius & 13 \\
\hline Aplysia parvula & 8 \\
\hline Polychaeta: Nereidae & 13 \\
\hline \multicolumn{2}{|l|}{ Non D. pulchra feeders } \\
\hline \multicolumn{2}{|l|}{ Amphipoda } \\
\hline Ampithoidae & 13 \\
\hline Hyalidae & 12 \\
\hline Aoridae & 12 \\
\hline Eusiridae & 12 \\
\hline \multicolumn{2}{|l|}{ Isopoda } \\
\hline Paridotea spp. ( $P$. munda and $P$. collingei) & 4 \\
\hline \multicolumn{2}{|l|}{ Insecta } \\
\hline Trichoptera & 2 \\
\hline
\end{tabular}

The most widespread mesograzers were the gastropod Phasianotrochus eximius, nereid polychaetes, and ampithoid amphipods, which were recorded at all 13 locations (Table 5). Three other families of known herbivorous amphipods; Hyalidae, Aoridae and Eusiridae were also widespread (Table 5) and were often abundant (Figs. 6 \& 7). Other mesograzers that were common, although less widespread, were juvenile Holopneustes purpurascens, the sea hare Aplysia parvula, isopods Paridotea munda and P. collingei, and caddis fly larvae (Trichopterans). Although $H$. purpurascens was recorded as a macroinvertebrate, juveniles of this species also occurred as mesograzers (see definition of mesograzers in 'Materials and methods') on Delisea pulchra and were included in the counts of mesograzer abundance. However, juvenile $H$. purpurascens are 


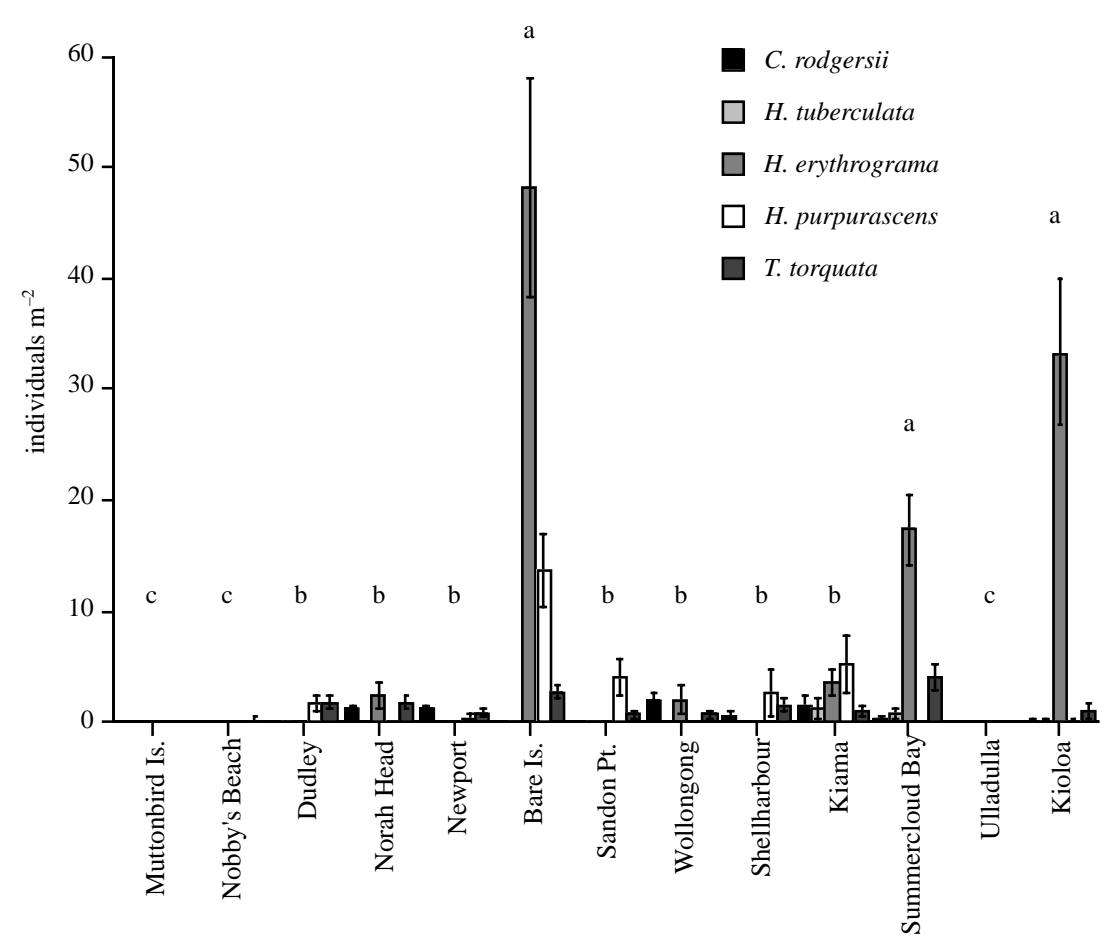

Fig. 5. Density of macroinvertebrate herbivores (mean $\pm 1 \mathrm{SE}$ ) at each location in summer 1995. One Turbo undulatus was found at Dudley (not shown). Locations sharing the same letter do not have a different total density of macroinvertebrates at $p=0.05$ (Tukey's analysis)

much heavier than any other mesograzers, and including them in the biomass analysis greatly biased the results to those locations where they occurred. Therefore, they were excluded from the analysis comparing total biomass of mesograzers among locations.

The total number of mesograzers known to consume Delisea pulchra (Table 5) differed significantly among locations (1-factor ANOVA $F_{12,116}=6.241, \mathrm{p}<0.001$ ) and ranged from 0.17 ind. $\mathrm{g}^{-1}$ of plant at Norah Head to 5.1 ind. $\mathrm{g}^{-1}$ of plant at Sandon Point (Fig. 6). Similarly, the total biomass of these mesograzers also differed significantly among locations (1-factor ANOVA; $F_{12,116}=6.117$, $\mathrm{p}<0.001$ ) and, in general, followed the same pattern as their total number (Fig. 7).

The most common epiphytes were foliose or filamentous species such as Ulva spp. and Enteromorpha spp., and Colpomenia sinuosa. The total epiphyte load differed significantly on plants from the different locations (1-factor ANOVA $F_{12,114}=2.179, \mathrm{p}=0.017$; Fig. 8). Mean total mass of epiphytes ranged from zero at Muttonbird Island to $106 \mathrm{mg} \mathrm{g}^{-1}$ (10.6\% of dry weight of plants) at Shellharbour.

\section{Correlations between secondary metabolites, herbivores and epiphytes}

The correlations between the mean total concentrations of furanones in plants from the different locations and the mean abundance of herbivores (macrograzers or mesograzers known to consume Delisea pulchra) or epiphyte loads were all weak and non-significant (Fig. 9). Correlations between individual compounds and herbivores and epiphytes were all similarly weak and non-significant ( $\mathrm{r}^{2}$ ranged from 0 to 0.085$)$.

\section{Proportion of life-history stages}

Populations of Delisea pulchra, with 1 exception, consisted entirely of tetrasporophytes or non-reproductive plants (Fig. 10). Often tetrasporophytes made up $100 \%$ of the plants present in the populations. Female gametophytes were found at only 1 of the 15 locations, Nobby's Beach, where they represented a small percentage of plants at both sampling times (10\% in winter 1994 and $19 \%$ in summer 1995). No male gametophytes were found at any locations in either season.

\section{Variation in secondary metabolites between life-history stages}

In winter 1994, there was no difference in the concentrations of total furanones in tetrasporophyte and gametophyte plants from Nobby's Beach (Student's $t_{11}=$ $-0.345, \mathrm{p}=0.737$; Fig 11a). There was also no difference between tetrasporophyte and gametophyte plants in the concentrations of individual furanones in winter 1994, although this was only marginally non-significant (Table 6). In summer 1995, tetrasporophytes had a sig- 

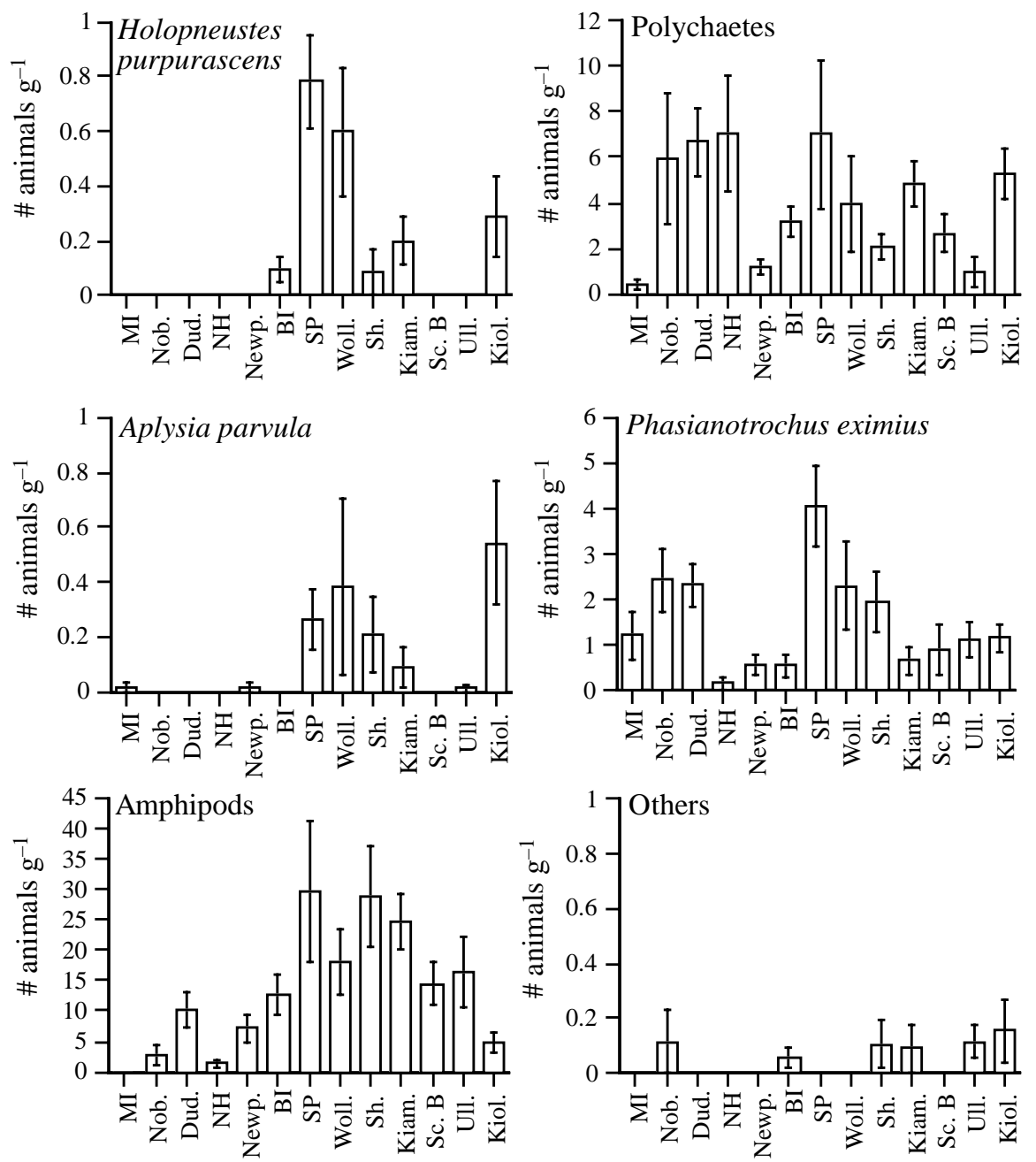

SP Woll. Nob. Sh. Dud. Kiol. Ull. MI Kiam. Sc.B BI Newp. NH
Fig. 6. Density of mesograzers (mean number of animals $\mathrm{g}^{-1}$ plant $\pm 1 \mathrm{SE}$ ) at each location in summer 1995. Results of Tukey's analysis on the total number of Delisea pulchra feeding mesograzers (see Table 4) are shown at the bottom. Locations that share a line do not differ at $\mathrm{p}=0.05$. Abbreviations: Muttonbird Island (MI), Nobby's Beach (Nob.), Dudley (Dud.), Norah Head (NH), Newport (Newp.), Bare Island (BI), Sandon Point (SP), Wollongong (Woll.), Shellharbour (Sh.), Kiama (Kiam.), Summercloud Bay (Sc B), Ulladulla (Ull.), and Kioloa (Kiol.) nificantly higher concentration of both total and individual furanones than female gametophytes and non-reproductive plants (Tukey's $\alpha<0.05$; Table 7, Fig. 11b). Individual compounds also differed in concentration, but this pattern did not vary among the different life-history stages (non-significant life history $\times$ compound interaction; Table 7).

\section{DISCUSSION}

\section{Patterns of variation in furanones, herbivores, epiphytes and life-history stages}

Furanones produced by Delisea pulchra varied significantly with space (among locations), time (winter vs summer) and life-history stage (diploid vs haploid), demonstrating a complex pattern of variation for the secondary metabolites of this alga. The range of furanones among plants within locations was large, often varying by an order of magnitude. Both the total and individual concentrations of furanones varied among locations in winter 1994 and summer 1995, but there was no latitudinal trend to this variation. This result for furanones in D. pulchra is similar to the absence of a latitudinal trend to the variation in phlorotannins in kelps and fucoids in the northeastern Pacific (Van Alstyne et al. 1999). A previous study of D. pulchra showed no significant difference in the concentrations of furanones in plants from 2 locations $10 \mathrm{~km}$ apart (de Nys et al. 1996). However, other macroalgae have shown among-site variation in concentrations of total phlorotannins (Steinberg 1989, Steinberg \& Van Altena 1992, Pavia \& Aberg 1996, Van Alstyne et al. 

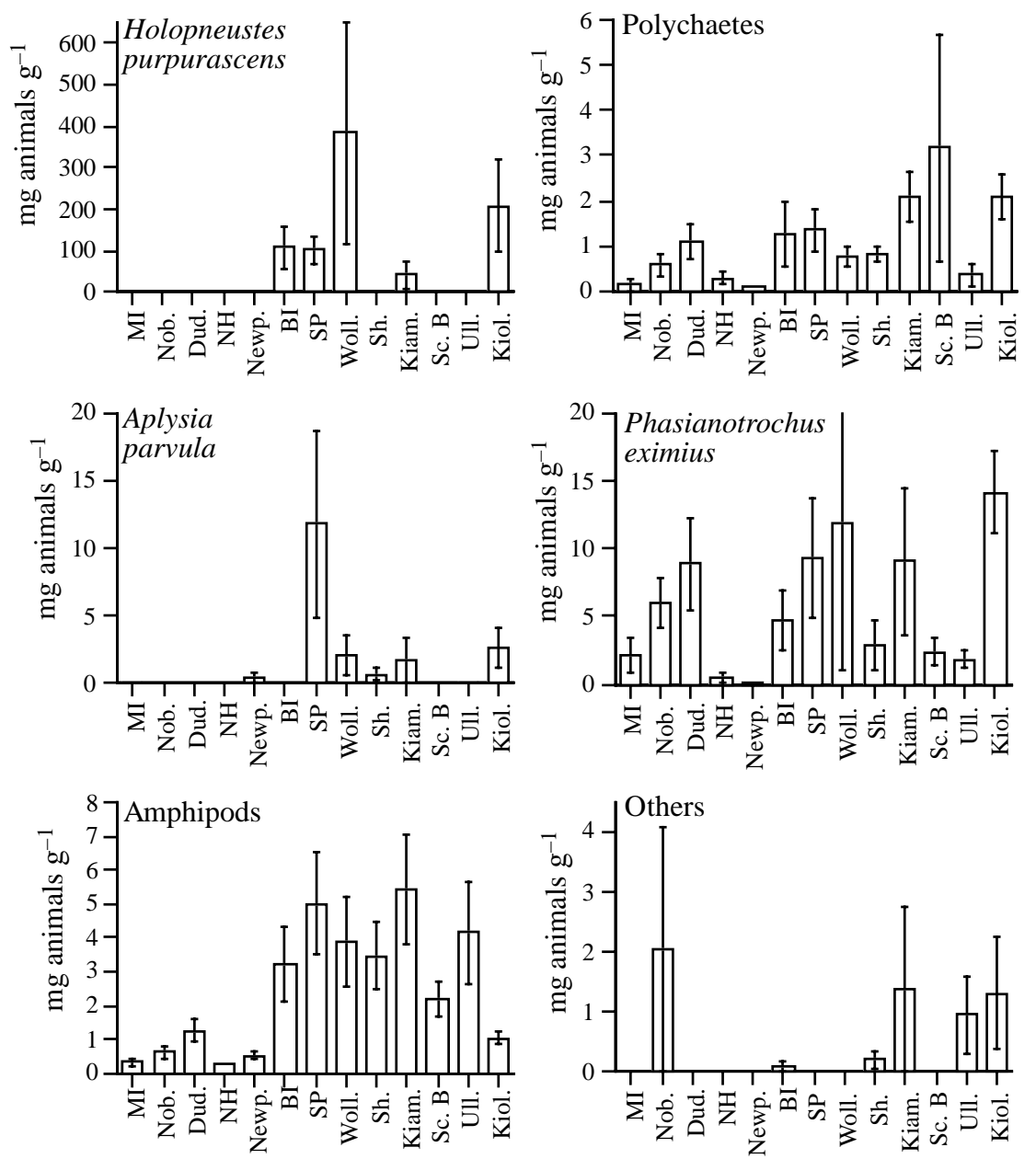

SP Kiol. Woll. Kiam. Dud. Nob. BI Sc.B Sh. Ull. MI NH Newp.
Fig. 7. Mass of mesograzers (mean mg mesograzers $\mathrm{g}^{-1}$ plant $\pm 1 \mathrm{SE}$ ) at each location in summer 1995. Results of Tukey's analysis on the total mass of Delisea pulchra feeding mesograzers (Table 4) are shown at the bottom. Locations that share a line do not differ at $p=0.05$. Location abbreviations as in Fig. 6

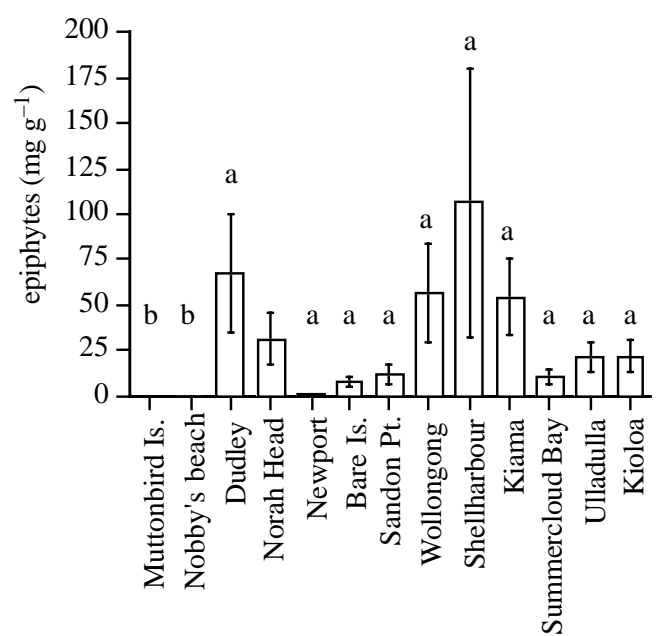

Fig. 8. Mass of epiphytes (mean $\mathrm{mg} \mathrm{g}^{-1}$ plant $\pm 1 \mathrm{SE}$ ) at each location in summer 1995. Locations sharing the same letter do not differ at $\mathrm{p}=0.05$ (Tukey's analysis)
1999) and non-polar secondary metabolites (Cronin \& Hay 1996c, Puglisi \& Paul 1997). The total concentration of furanones also varied with time, with levels generally being lower in summer, although this varied with location (Fig. 3). Temporal variation in secondary metabolites has also been observed in other macroalgae (Steinberg 1989, Steinberg \& Van Altena 1992, Yates \& Peckol 1993, Cronin \& Hay 1996c, Peckol et al. 1996).

Concentrations of the 4 individual compounds differed within plants in both winter 1994 and summer 1995, but as with total furanones, these differences were not consistent across locations or time (see significant interactions between compound, location and time; Table 3). At different locations and/or times, Compounds 3, 4 and 1 were the most abundant. This complex and variable pattern of furanone production in Delisea pulchra suggests that variation may be a response to location- and time-specific factors. It also 

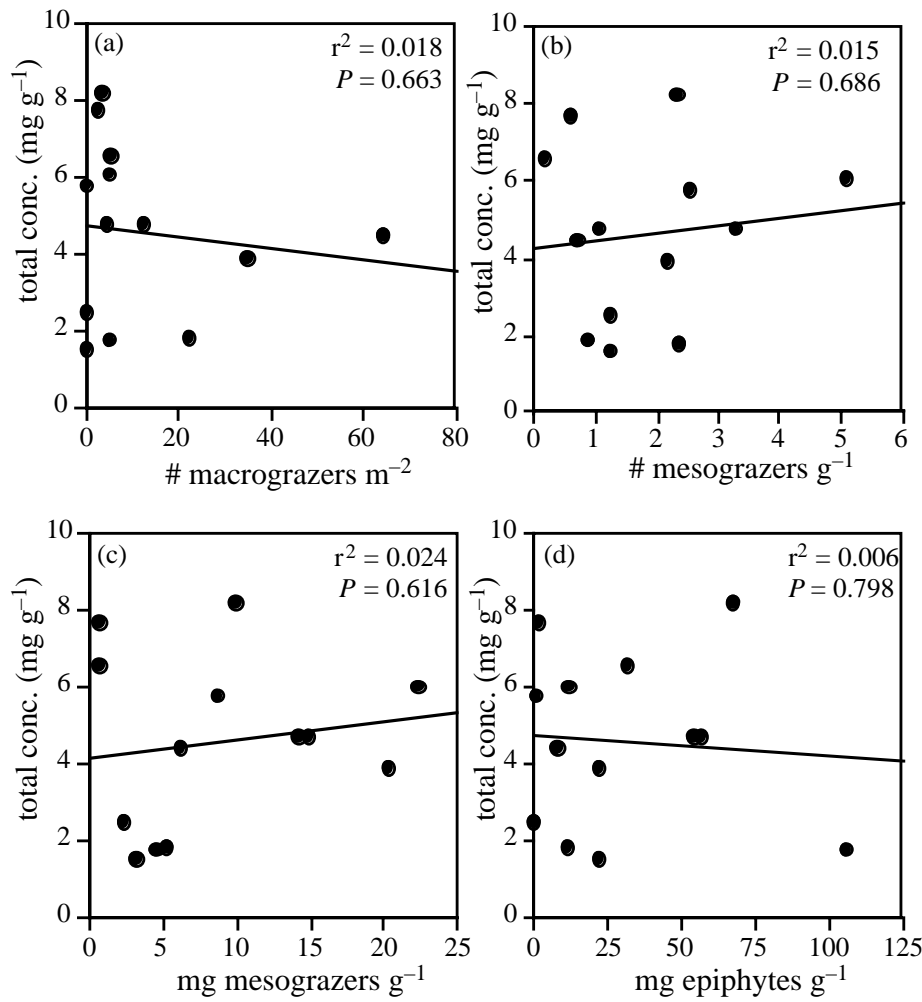

Fig. 9. Relationships between total furanones and (a) density of macroinvertebrate herbivores, (b) density of mesograzers known to consume Delisea pulchra, (c) biomass of mesograzers known to consume $D$. pulchra, and (d) epiphyte load at 13 locations in summer 1995

indicates that studies examining patterns of variation in algal secondary metabolites need to be adequately replicated in space and time to ensure that the sampling provides an accurate examination.

The abundance of macroinvertebrates, mesograzers and epiphytes differed significantly among locations, but also with no evidence of a latitudinal trend. The abundance of macrograzers also varied significantly among sites within locations, indicating small-scale patchiness in their abundance. Small-scale patchiness in the abundance of temperate marine herbivores is well documented (e.g. Underwood et al. 1991). The large sea urchin Centrostephanus rodgersii is generally considered the most important subtidal grazer in southeastern Australia (Fletcher 1987, Andrew 1993). However, it is found deeper than where Delisea pulchra is most abundant and was rare or absent at the locations sampled here. The 3 most common macrograzers that co-occurred with D. pulchra (Heliocidaris erythrograma, Holopneustes purpurascens, Turbo torquatus) consume D. pulchra; however, their impact on it is probably minimal as it is a low-preference food for all of them (Wright et al. unpubl.). D. pulchra is also a lowpreference food for 2 other less common herbivores: the
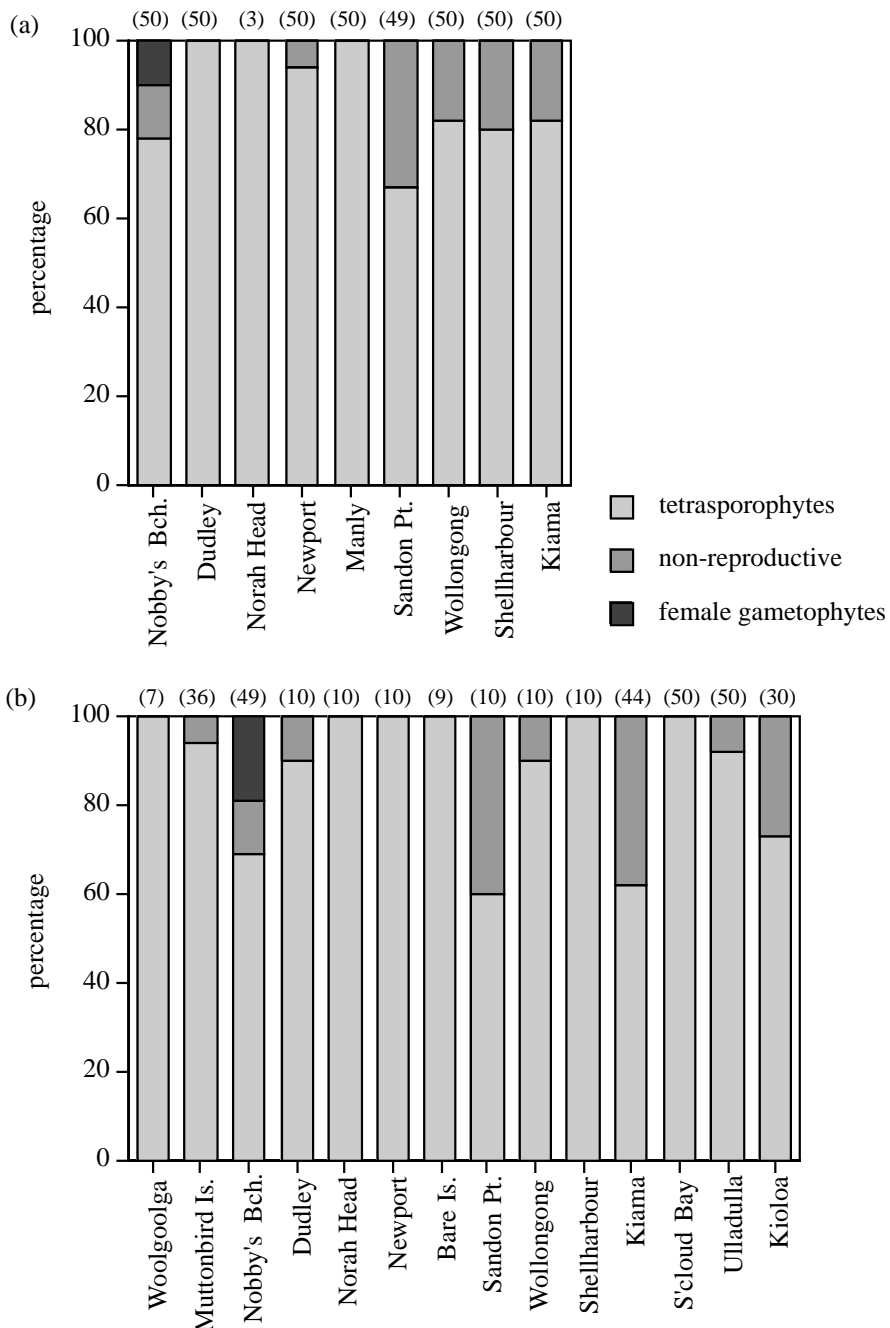

Fig. 10. Percentage of different life-history stages (tetrasporophytes, non-reproductive plants and female gametophytes) of Delisea pulchra found at each location in (a) winter 1994 and (b) summer 1995. The number of plants sampled at each location in each survey is shown in brackets

gastropod Turbo undulatus and the sea urchin Tripneustes gratilla (Steinberg \& Van Altena 1992).

The most abundant mesograzers found in this study were amphipods (Fig. 6). No species of amphipod has been recorded as consuming Delisea pulchra in southeastern Australia (A. Poore pers. comm.) and those found were most likely consuming epiphytes. At least 1 species of nereid polychaete is known to consume $D$. pulchra. However, whilst at least 8 other polychaete families contain herbivorous species (Brawley 1992), we probably overestimated the number of herbivores by counting total polychaetes. The other common mesograzers (Phasianotrochus eximius, Aplysia parvula, Holopneustes purpurascens) consume D. pulchra. P. eximius and $A$. parvula prefer the chemically rich tips of $D$. pulchra (a relatively small proportion of the total 


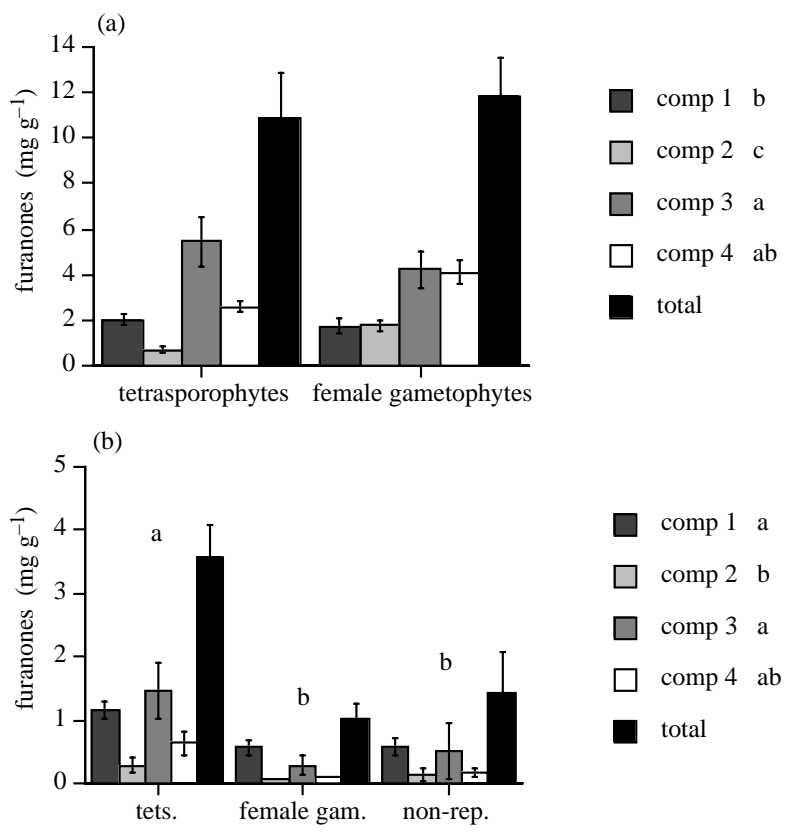

Fig. 11. Concentrations (mean $\pm 1 \mathrm{SE}$ ) of furanones in different life-history stages collected from Nobby's Beach. (a) Total and individual furanones (Compounds 1 to 4 ) in tetrasporophytes $(\mathrm{n}=8)$ and female gametophytes $(\mathrm{n}=5)$ in winter 1994 . (b) Total and individual furanones (Compounds 1 to 4) in tetrasporophytes (tets.), female gametophytes (female gam.) and non-reproductive (non-rep.) plants in summer 1995 ( $\mathrm{n}=5$ for all life-history stages). Life-history stages or compounds sharing the same letter do not differ at $p=0.05$ (Tukey's analysis)

plant biomass) to other parts of the plant and are not deterred by crude extract at natural concentration (Rogers 2000, Wright et al. unpubl.).

Haploid plants of Delisea pulchra were found at only 1 of the 15 locations sampled, Nobby's Beach. All plants at the other locations were tetrasporophytes or juveniles. Significantly, this result was consistent over both winter and summer. D. pulchra is known to recycle tetrasporophytes via spores (Wright 2000) and clones have been described in $D$. pulchra populations (Wright et al. 2000). The results from this study indicate that asexual reproduction of tetrasporophytes is

Table 6. ANOVA comparing individual furanones (Compounds 1 to 4 ) in different life-history stages of Delisea pulchra (tetrasporophytes vs gametophytes) at Nobby's Beach in winter 1994. Data $\log (x+1)$ transformed

\begin{tabular}{|lrrrr|}
\hline Source & df & MS & $F$ & \multicolumn{1}{c|}{$p$} \\
\hline Life history & 1 & 0.075 & 3.862 & 0.057 \\
Compound & 3 & 0.152 & 7.873 & $<0.001$ \\
Plant (block) & 7 & 0.054 & 2.777 & 0.020 \\
Life history $\times$ Compound & 3 & 0.031 & 1.595 & 0.207 \\
Error & 37 & 0.019 & & \\
\hline
\end{tabular}

Table 7. ANOVAs comparing total and individual furanones (Compounds 1 to 4 ) in different life-history stages of Delisea pulchra (tetrasporophytes, gametophytes and non-reproductive plants) at Nobby's Beach in summer 1995. Data $\log (x+1)$ transformed

\begin{tabular}{|lrcrc|}
\hline Source & df & MS & $F$ & $p$ \\
\hline Total furanones & & & & \\
Life history & 2 & 0.980 & 7.695 & 0.007 \\
Error & 12 & 0.127 & & \\
Individual furanones & & & & \\
Life history & 2 & 0.812 & 13.944 & $<0.001$ \\
Compound & 3 & 0.531 & 9.115 & $<0.001$ \\
Plant (block) & 4 & 0.057 & 0.983 & 0.426 \\
Life history $\times$ Compound & 6 & 0.053 & 0.907 & 0.499 \\
Error & 44 & 0.058 & & \\
\hline
\end{tabular}

widespread in D. pulchra populations in southeastern Australia. Variation in the proportion of different lifehistory stages among populations of red algae is well documented (Hawkes 1990). Often this is dependent on latitude, suggesting that environmental factors such as photoperiod and temperature are important in determining specific patterns of life history at a given site (Hawkes 1990, Santelices 1990). Over the geographic range surveyed here, there was no evidence for a latitudinal trend in the proportion of different life-history stages of $D$. pulchra. However, in a different biogeographical region there is some evidence this may occur, as D. pulchra sampled from Macquarie Island by Ricker (1987) were all gametophytes. The reason for the lack of gametophytes in the populations in New South Wales is not clear.

\section{Relationship between furanones, herbivores and epiphytes}

At the level of population, correlations between total and individual furanones and the abundance of macrograzers, mesograzers and epiphytes were weak and non-significant (Fig. 9). These results are in contrast to the correlation between high levels of phlorotannins and high levels of herbivory in temperate Australasian versus temperate North American brown algae (Steinberg 1989, 1992, Steinberg et al. 1995) and to the correlation between feeding deterrence of non-polar extracts and high herbivory in tropical versus temperate algae (Bolser \& Hay 1996). The conclusions reached from those studies was that a historically high intensity of herbivory in Australasia and the tropics was important in driving the evolution of high concentrations of secondary metabolites in algae in those regions. There was no evidence that high densities of herbivores within populations have had a similar effect on the 
concentrations of furanones in D. pulchra. Our results also show no evidence to indicate induction of furanones by herbivores.

One constraint on any ecological or evolutionary interpretation is the assumption that the densities of herbivores and epiphytes in each of the locations at the time of sampling were indicative of their densities over ecological and evolutionary time-scales may not be valid. Temporal variation in the abundance of marine herbivores is widely documented and the abundance of Heliocidaris erythrograma (Wright \& Steinberg in press), Holopneustes purpurascens (Steinberg 1995), Centrostephanus rodgersii (Andrew 1991), and Aplysia parvula (Rogers 2000) show considerable variability in time at single locations. A second constraint on our conclusions is that given the large within-location variation in furanones, by examining the relationships between furanones, herbivores and epiphytes at population level, evidence for processes acting upon individuals may have been obscured. Examining those relationships more rigorously within populations will probably reveal more about the role of herbivores and epiphytes in the evolution of quantitative variation in algal secondary metabolites. A third constraint relates to our sampling. Given the distance covered in our surveys $(650 \mathrm{~km})$, it was not possible to control for environmental factors that may have varied between the different times the locations were sampled. For example, factors such as water temperature (via upwelling events), storms, UV light and nutrients may have varied among times and affected furanones, herbivores or epiphytes.

There are 2 further reasons that may explain the absence of a relationship between variation in furanones and variation in epiphytes. First, by measuring whole-plant chemistry, we were probably not measuring the levels of furanones encountered by epiphytes on the surface of the plants. Furanone levels of whole plants are, in general, not well correlated with surface furanone levels (Dworjanyn et al. 1999). Second, it is possible that by measuring epiphytes only on Delisea pulchra, we may not have adequately sampled the abundance of epiphytes, and thus their overall abundance, at each location. Differences in the degree of epiphytism on D. pulchra among locations could arise because of: (1) differences in the abundance of epiphytes at each location; (2) differences in chemical resistance of $D$. pulchra to epiphytes at each location.

Factors contributing to the quantitative variation in algal secondary metabolites fall into 2 broad categories: environmental (ecological) and genetic (evolutionary). Previous work in marine algae has focussed solely on the effects of environmental factors such as nutrients (carbon, nitrogen; Yates \& Peckol 1993, Arnold et al. 1995, Cronin \& Hay 1996a, Puglisi \& Paul
1997), light (UV, visible; Cronin \& Hay 1996a, Pavia et al. 1997, Puglisi \& Paul 1997), desiccation (Cronin \& Hay 1996b); or induction due to herbivory (Van Alstyne 1988, Cronin \& Hay 1996a, Peckol et al. 1996). The low concentration of furanones in Delisea pulchra in summer 1995 (Figs. 3 \& 4) may reflect the impact of high UV light in that season. However, as the concentration of furanones did not follow a latitudinal cline, environmental factors such as temperature and light that may vary over this geographic range do not appear to be the major cause of the differences among locations. The effect of nutrients in contributing to the differences in concentrations of furanones among locations is unclear.

Quantitative variation in total furanones and Compound 3 from Delisea pulchra show significant heritability (Wright 2000), indicating the potential for an evolutionary response. However, in general, feeding by herbivores does not vary with furanone concentration (Wright et al. unpubl.). In addition, surface concentrations of furanones are usually high enough to deter settlement of epiphytic algal propagules (de Nys et al. 1998, Dworjanyn et al. 1999). Thus, variation in the response of herbivores and epiphytes to different concentrations of furanones, which is necessary for them to impose selective pressure on quantitative variation of furanones, may be absent.

Finally, the large within-location variability in furanone concentration of Delisea pulchra supports the hypothesis of Karban et al. (1997) that variability itself can be the target of selection. This model proposes that variability can be favoured because as variability increases, benefits to herbivores decrease as it becomes more difficult for a herbivore to adapt to a defence. Concentrations of furanones not only vary among individual plants, but can also vary significantly among parts within individual plants (de Nys et al. 1996, Dworjanyn et al. 1999), further supporting this hypothesis.

\section{Conclusions}

The concentrations of secondary metabolites in Delisea pulchra varied among locations but did not vary in a predictable way with latitude or the abundance of herbivores and epiphytes. The lack of clinal variation in furanones suggests that environmental factors that vary with latitude (water temperature, light) are unlikely to be causing the variation observed among locations. The weak correlations between the abundance of herbivores, epiphytes and furanones suggest that quantitative variation in the secondary metabolites of $D$. pulchra is not driven by population-level selection or induction but by localised variation in environmental factors such as nutrients, or by genetic 
differences among individual plants. Alternatively, it may be that looking for a correlation between secondary metabolites and herbivores or epiphytes at the scale of location obscures processes that are affecting individual plants. The large within-location variation in all of the factors examined, particularly concentrations of furanones, suggests that small-scale processes are more likely to be important in driving quantitative variation in the secondary metabolites of $D$. pulchra than large geographic-scale processes.

Acknowledgements. We are grateful for assistance provided by Harri Baillie, Rachel Bathgate, Alistair Poore, Cary Rogers and Josh Stern. J.T.W was supported by an Australian postgraduate award (APA), and R.d.N. by an Australian Research Council (ARC) post-doctoral research fellowship. This research was supported by the ARC and the Centre for Marine Biofouling and Bio-Innovation.

\section{LITERATURE CITED}

Andrew NL (1991) Changes in subtidal habitat following mass mortality of sea urchins in Botany Bay, New South Wales. Aust J Ecol 16:353-362

Andrew NL (1993) Spatial heterogeneity, sea urchin grazing, and habitat structure on reefs in temperate Australia. Ecology 74:292-302

Andrew NL, Jones GP (1990) Patch formation by herbivorous fish in a temperate Australian kelp forest. Oecologia 85: $57-68$

Arnold TM, Tanner CE, Hatch WI (1995) Phenotypic variation in polyphenolic content of the tropical brown alga Lobophora variegata as a function of nitrogen availability. Mar Ecol Prog Ser 123:177-183

Bolser RC, Hay ME (1996) Are tropical plants better defended? Palatability and defenses of temperate vs. tropical seaweeds. Ecology 77:2269-2286

Bonin DR, Hawkes MW (1988) Systematics and life histories of the New Zealand Bonnemaisoneaceae (Bonnemaisonales, Rhodophyta): II. The genus Delisea. NZ J Bot 26: 619-632

Brawley SH (1992) Mesoherbivores. In: John DM, Hawkins SJ, Price JH (eds) Plant-animal interactions in the marine benthos. Clarendon Press, Oxford, p 235-263

Choat JH (1982) Fish feeding and the structure of benthic communities in temperate waters. Annu Rev Ecol Syst 13: 423-449

Choat JH, Clements KD (1992) Diet in odacid and aplodactylid fishes from Australia and New Zealand. Aust J Mar Freshw Res 43:1451-1459

Cronin G, Hay ME (1996a) Effects of light and nutrient availability on the growth, secondary chemistry, and resistance to herbivory of two brown seaweeds. Oikos 77:93-106

Cronin G, Hay ME (1996b) Susceptibility to marine herbivores depends on recent history of both the plant and animal. Ecology 77:1531-1543

Cronin G, Hay ME (1996c) Induction of seaweed chemical defences by amphipod grazing. Ecology 77:2287-2301

de Nys R, Coll JC, Bowden BF (1992) Delisea pulchra (cf. fimbriata) revisited. The structural determination of two new metabolites from the red alga Delisea pulchra. Aust J Chem 45:1625-1632 de Nys R, Wright AD, Konig GM, Sticher O (1993) New halogenated furanones from the marine alga Delisea pulchra (cf. fimbriata). Tetrahedron 49:11213-11220

de Nys R, Steinberg PD, Willemson P, Dworjanyn SA, Gabelish CL, King RJ (1995) Broad spectrum effects of secondary metabolites from the red alga Delisea pulchra in antifouling assays. Biofouling 8:259-271

de Nys R, Steinberg PD, Rogers CN, Charlton TS, Duncan MW (1996) Quantitative variation of secondary metabolites in the sea hare Aplysia parvula and its host plant, Delisea pulchra. Mar Ecol Prog Ser 130:135-146

de Nys R, Dworjanyn SA, Steinberg PD (1998) A new method for determining surface concentrations of marine natural products on seaweeds. Mar Ecol Prog Ser 162:79-87

Dworjanyn SA, de Nys R, Steinberg PD (1999) Localisation and surface quantification of secondary metabolites in the red alga Delisea pulchra. Mar Biol 133:727-736

Fletcher WJ (1987) Interactions among subtidal Australian sea urchins, gastropods, and algae: effects of experimental removals. Ecol Monogr 57:89-109

Fritz RS, Simms EL (1992) Plant resistance to herbivores and pathogens. The University of Chicago Press, Chicago

Hawkes MH (1990) Reproductive strategies. In: Cole KM, Sheath RG (eds) Biology of the red algae. Cambridge University Press, Cambridge, p 455-476

Hay ME (1996) Marine chemical ecology: what's known and what's next? J Exp Mar Biol Ecol 200:103-134

Hay ME, Steinberg PD (1992) The chemical ecology of plantherbivore interactions in marine versus terrestrial communities. In: Rosenthal GA, Berembaum MR (eds) Herbivores: their interaction with secondary plant metabolites, Vol 2. Evolutionary and ecological processes. Academic Press, San Diego, p 371-413

Hay ME, Duffy JE, Pfister CA, Fenical W (1987) Chemical defense against different marine herbivores: are amphipods insect equivalents? Ecology 68:1567-1580

Jeffrey SW, Rochford DJ, Creswell GR (1990) Oceanography of the Australasian region. In: Clayton MN, King RJ (eds) Biology of marine plants. Longman Cheshire Pty Ltd, Melbourne, p 243-265

Karban R, Agrawal AA, Mangel M (1997) The benefits of induced defences against herbivores. Ecology 78:1351-1355

Maximilien R, de Nys R, Holmstrom C, Gram L, Giskov M, Crass K, Kjelleberg S, Steinberg PD (1998) Chemical mediation of bacterial surface colonisation by secondary metabolites from the red alga Delisea pulchra. Aquat Microb Ecol 15:233-246

Millar AJK (1990) Marine algae of the Coffs Harbour region, northern New South Wales. Aust Syst Bot 3:293-593

Pavia H, Aberg P (1996) Spatial variation in polyphenolic content of Ascophyllum nodosum (Fucales, Phaeophyta). Hydrobiologia 326/327:199-203

Pavia H, Cervin G, Lindgren A, Aberg P (1997) Effects of UV$\mathrm{B}$ radiation and simulated herbivory on phlorotannins in the brown alga Ascophyllum nodosum. Mar Ecol Prog Ser 157:139-146

Peckol P, Krane KM, Yates JL (1996) Interactive effects of inducible defense and resource availability on phlorotannins in the North Atlantic brown alga Fucus vesiculosus. Mar Ecol Prog Ser 138:209-217

Pennings SC, Paul VJ (1993) Sequestration of dietary secondary metabolites by three species of sea hares: location, specificity and dynamics. Mar Biol 117:535-546

Poore AGB, Steinberg PD (1999) Preference-performance relationships and effects of host plant choice in a herbivorous marine amphipod. Ecol Monogr 69:443-464

Puglisi MP, Paul VJ (1997) Intraspecific variation in the red 
alga Portieria hornemannii: monoterpene concentrations are not influenced by nitrogen or phosphorus enrichment. Mar Biol 128:161-170

Ricker RW (1987) Taxonomy and biogeography of Macquarie Island seaweeds. British Museum (Natural History), London

Rogers CN (2000) The costs and benefits of acquired algal secondary metabolites to Aplysia parvula. PhD thesis, University of New South Wales

Rogers CN, Steinberg PD, de Nys R (1995) Factors associated with oligophagy in two species of sea hares (Mollusca: Anapsidea). J Exp Mar Biol Ecol 192:47-73

Rosenthal GA, Berenbaum MR (1992) Herbivores: their interaction with plant secondary metabolites, Vols 1 and 2, 2nd edn. Academic Press, San Diego

Santelices B (1990) Patterns of reproduction, dispersal and recruitment in seaweeds. Oceanogr Mar Biol Annu Rev 28:177-276

Schmitt TM, Hay ME, Lindquist N (1995) Constraints on chemically mediated coevolution: multiple functions for seaweed secondary metabolites. Ecology 76:107-123

Steinberg PD (1988) Effects of quantitative and qualitative variation in phenolic compounds on feeding in three species of marine invertebrate herbivores. J Exp Mar Biol Ecol 120:221-237

Steinberg PD (1989) Biogeographical variation in brown algal polyphenolics and other secondary metabolites: comparison between temperate Australasia and North America. Oecologia 78:374-383

Steinberg PD (1992) Geographical variation in the interaction between marine herbivores and brown algal secondary metabolites. In: Paul VJ (ed) Ecological roles for marine secondary metabolites. Cornell University Press, Ithaca, p 51-92

Steinberg PD (1995) Interaction between the canopy dwelling echinoid Holopnuestes purpurescens and its host kelp Ecklonia radiata. Mar Ecol Prog Ser 127:169-181

Steinberg PD, Van Altena I (1992) Tolerance of marine invertebrate herbivores to brown algal phlorotannins in temperate Australasia. Ecol Monogr 62:189-222

Steinberg PD, Estes JA, Winter FC (1995) Evolutionary conse-

Editorial responsibility: Joseph Pawlik (Contributing Editor), Wilmington, North Carolina, USA quences of food chain length in kelp forest communities. Proc Natl Acad Sci 92:8145-8148

Targett NM, Arnold TM (1998) Predicting the effects of brown algal phlorotannins on marine herbivores in tropical and temperate oceans. J Phycol 34:195-205

Targett NM, Coen LD, Boettcher AA, Tanner CE (1992) Biogeographic comparisons of marine algal polyphenolics: evidence against a latitudinal trend. Oecologia 89:464-470

Underwood AJ, Kingsford MJ, Andrew NL (1991) Patterns in shallow subtidal marine assemblages along the coast of New South Wales. Aust J Ecol 6:231-249

Van Alstyne KL (1988) Herbivore grazing increases polyphenolic defenses in the intertidal brown alga Fucus distichus. Ecology 69:655-663

Van Alstyne KL, Paul VJ (1990) The biogeography of polyphenolic compounds in marine macroalgae: temperate brown algal defenses deter feeding by tropical herbivorous fishes. Oecologia 84:158-163

Van Alstyne KL, McCarthy JJ, Hustead CL, Duggins DO (1999) Geographic variation in polyphenolic levels of Northeastern Pacific kelps and rockweeds. Mar Biol 133:371-379

Wilkinson L (1997) SYSTAT 7.0. SPSS Inc, Chicago, IL

Womersley HBS (1990) Biogeography of Australasian macroalgae. In: Clayton MN, King RJ (eds) Biology of marine plants. Longman Cheshire Pty Ltd, Melbourne, p 367-381

Womersley HBS (1996) The marine benthic flora of southern Australia. Part IIIB. South Australia Government Printing Division, Adelaide

Wright JT (2000) Population dynamics, genetic structure and evolution of chemical defences in a marine alga. $\mathrm{PhD}$ thesis, University of New South Wales

Wright JT, Steinberg PD (in press) Effects of variable recruitment and post-recruitment herbivory on local population size of a marine alga. Ecology

Wright JT, Zuccarello GC, Steinberg PD (2000) Genetic structure in the subtidal red alga Delisea pulchra. Mar Biol 136: 439-448

Yates JL, Peckol P (1993) Effects of nutrient availability and herbivory on polyphenolics in the seaweed Fucus vesiculosus. Ecology 74:1757-1766

Submitted: April 18, 2000; Accepted: August 15, 2000

Proofs received from author(s): October 25, 2000 